\title{
Studies on Protein Synthesis in Kappa Particles
}

\author{
By HELMUT J. SCHMIDT $†$ \\ Department of Biology, Indiana University, Jordan Hall 138, Bloomington, Indiana 47405, USA
}

(Received 12 August 1983; revised 15 December 1983)

Further evidence that kappa endosymbionts of stock 7 Paramecium biaurelia [Caedibacter varicaedens] are bacteria is given by the discovery of a prokaryotic translational system in these particles. Kappa proteins incorporate ${ }^{35} \mathrm{~S}$ in in vivo experiments. However, there is no evidence that the translational systems of the host paramecia and the symbionts are shared. On the contrary, experiments with symbiont-bearing and symbiont-free strains strongly indicate that all major proteins found in kappa are synthesized in kappa. In this respect, kappa clearly differs from cell organelles. Protein synthesis in kappa is not inhibited by cycloheximide and the aminoglycoside $\mathrm{G} 418$, which do inhibit, although not completely, protein synthesis of the host cells. On the other hand, chloramphenicol quantitatively blocks translation in kappa without any obvious effects on the translational system of the paramecium cytoplasm.

Stock 7 kappa was isolated and purified using a filter paper column. The purity of kappa preparations thus obtained was significantly improved by adding a preliminary deciliation step.

\section{INTRODUCTION}

Kappa and other endosymbionts are Gram-negative bacteria, living in the cytoplasm or nucleus of Paramecium and other ciliated protozoa. They obviously profit from their host, acquiring from it all necessary nutrients, and their intracellular site offers protection from the external environment. Adaptation to an intracellular mode of life has led to degenerative changes: most symbionts are slow growing, and have lost their capacity to grow outside their host. The genome size of several endosymbionts appears to be small (Soldo \& Godoy, 1973, 1974; Schmidt, 1982), and the genome seems to be present in a rather high number of copies (520) per cell. Numerous other studies have shown the closeness of the relationship between symbionts and host. For instance, many symbionts depend for their maintenance on genes in the host genome (Balsley, 1966; Preer et al., 1974a). Studies by Beale \& Jurand (1966) indicated that the degree of specificity between these genes and the symbionts is very high. Stock 51 kappa contains an antigen which is found in the cytoplasm of kappa-bearing cells, but not in sensitive, symbiont-free strains (Mueller, 1966). Furthermore, strong arguments exist (Preer, 1977) that the association of kappa and Paramecium is very ancient, perhaps going back to pre-Cambrian times. If this is true, then Sonneborn's original view that kappa is an intrinsic organelle of Paramecium may be more accurate than the view that it is merely a parasite (for reviews see Sonneborn, 1959; Preer et al., 1974a; Preer \& Preer, 1983).

One of the most important discoveries on cell organelles such as mitochondria and chloroplasts during the past 15 years was the finding that they contain an independent system of protein synthesis. Although a number of mitochondrial proteins are synthesized by the cytoplasm, some are made in the organelles themselves (for reviews see Ashwell \& Work, 1970; Poyton \& Groot, 1975; Tzagoloff et al., 1979). The results reported here demonstrate that in this

† Present address : Zoologisches Institut, Westfälische Wilhelms-Universität, Badestrasse 9, D-4400 Münster, FRG.

Abbreviation: PMSF, phenylmethylsulphonyl fluoride. 
respect kappa is much more autonomous than cell organelles. It does have an independent system of protein synthesis, but there is no evidence for a coordinate regulation of the kappa and the paramecium translational systems. No proteins synthesized in the cytoplasm could be found in kappa.

\section{METHODS}

Cultures. Stock 7 of Paramecium biaurelia with Caedibacter varicaedens (Preer \& Preer, 1982, 1983), commonly known as $7 \mathrm{kappa}$, from the Indiana collection of paramecia was used and cultured as described previously (Sonneborn, 1950) in Cerophyl culture medium on Klebsiella pneumoniae. Cultures were purified by washing single cells in several changes of the following sterile solution : yeast autolysate, $1.33 \mathrm{~g}^{-1}$ (Basamin Bush, Bush Co., St Louis, Missouri, USA); 2.5 mM-sodium acetate; Cerophyl, $0.88 \mathrm{~g} \mathrm{l}^{-1} ; 1.2 \mathrm{mM}-\mathrm{Na}_{2} \mathrm{HPO}_{4}$ (Preer et al., 1974b). Purified cultures were kept monoxenically throughout the course of this study.

Isolation of kappa-free cells. Sensitive (kappa-free, 7S) cells were obtained as follows: a kappa-bearing (7K) culture was grown for one week at maximum fission rate $\left(27^{\circ} \mathrm{C}\right)$ with aureomycin $\left(0.04 \mathrm{mg} \mathrm{ml}^{-1}\right)$ present for the first day of incubation. Single cells were isolated, grown up at the low fission rate of one fission per day for three weeks into small cultures and tested for the presence of kappa. Cell lines without kappa particles were selected by examining crushed cells (Preer \& Stark, 1953) and were tested further for their 'spin killing' (Sonneborn, 1970) reaction against cells of stock $152(P$. triaurelia), which is very sensitive to the presence of $7 \mathrm{kappa}$. Once established, 7S cultures were also kept monoxenically.

Methods of labelling. Paramecia and their kappa symbionts were labelled with ${ }^{35} \mathrm{~S}$ by feeding them radioactively labelled bacteria, prepared by growth overnight at $37^{\circ} \mathrm{C}$ with vigorous shaking in a low-sulphate medium with $\mathrm{Na}_{2}{ }^{35} \mathrm{SO}_{4}$. The low-sulphate medium contained: $0.19 \mathrm{M}$-Tris, $0.07 \mathrm{M}-\mathrm{NH}_{4} \mathrm{Cl}, 0.05 \mathrm{M}-\mathrm{KCl}, 0.17 \mathrm{M}-\mathrm{HCl}, 3.4 \mathrm{mM}-$ $\mathrm{Na}_{2} \mathrm{HPO}_{4}, 0.33 \mathrm{mM}-\mathrm{MgCl}_{2} . \mathrm{H}_{2} \mathrm{O}, 0.38 \%$ glucose, $0.06 \mathrm{mM}-\mathrm{Na}_{2} \mathrm{SO}_{4}, 7.5 \mu \mathrm{Ci}(277.5 \mathrm{kBq}) \mathrm{Na}_{2}{ }^{35} \mathrm{SO}_{4} \mathrm{ml}^{-1}$. The labelled bacteria were harvested by centrifugation (Sorvall $\mathrm{SS} 34,4^{\circ} \mathrm{C}, 12000 \mathrm{~g}, 10 \mathrm{~min}$ ), washed twice and then resuspended in $1 \mathrm{ml}$ Dryl's solution (Dryl, 1959), and incubated for $15 \mathrm{~min}$ at $30^{\circ} \mathrm{C}$ in the presence of lysozyme $\left(1 \mathrm{~m} \mathrm{ml}^{-1}\right)$. Then $1 \mathrm{mg}$ proteinase $\mathrm{K}$ was added and the incubation was extended overnight. The mixture was autoclaved and fed to a $200 \mathrm{ml}$ paramecium culture (750-1000 cells ml-1). Cycloheximide, $1-2 \mathrm{mg} \mathrm{ml}^{-1}$, chloramphenicol, $0.4 \mathrm{mg} \mathrm{ml}^{-1}$ (Sigma) and the aminoglycoside G418, $50 \mu \mathrm{g} \mathrm{ml}^{-1}$ (Scherring Corp., Bloomfield, NJ, USA; Law et al., 1983) were used for inhibition of protein synthesis.

Experiments to label isolated kappa particles in vitro were carried out as follows: kappa particles from a $200 \mathrm{ml}$ culture were resuspended in $80 \mu \mathrm{l}$ mannitol/PMSF (10 $\mu \mathrm{l}$ PMSF stock per ml $0.6 \mathrm{M}$-mannitol: PMSF stock, $0.1 \mathrm{~g}$ in $2 \mathrm{ml}$ ethanol) and incubated for $50 \mathrm{~min}$ at $30^{\circ} \mathrm{C}$ in a mixture containing $\left[{ }^{35} \mathrm{~S}\right]$ methionine, which has previously been used successfully for in vitro labelling of mitochondria (Steinkeler \& Mahler, 1980). Incorporation was determined according to Steinkeler \& Mahler (1980), using a model LS100C Beckman scintillation counter.

Isolation of kappa particles. A portion ( $1 \mathrm{~g}$ ) of a filter paper ashless tablet (Whatman) was resuspended in water, poured into a $20 \mathrm{ml}$ pipette with some glass wool in the tip, and washed with $100 \mathrm{ml} \mathrm{H}_{2} \mathrm{O}$ and with $100 \mathrm{ml} 0.01 \mathrm{M}$ sodium phosphate buffer ( $\mathrm{pH}$ 7). A homogenate of paramecia (in $1 \mathrm{ml}$ Dryl's solution) was carefully laid on the column. The column was washed with about $500 \mathrm{ml} 0.01 \mathrm{M}$-sodium phosphate buffer (pH 7) at a rate of 1 drop s-1. Pure kappa particles were eluted with $0.01 \mathrm{M}$-sodium phosphate buffer, containing $0.5 \mathrm{M}-\mathrm{NaCl}(\mathrm{pH} 8)$ in eight fractions of $1.5 \mathrm{ml}$ each. These fractions were centrifuged (Sorvall SS34, 17000 g) and the kappa particles were pooled and stored frozen. This isolation procedure is a modification of the methods used by Preer $e t$ al. (1966). In some experiments the paramecia were deciliated before homogenization as follows. Cells were filtered through cotton and centrifuged in an IEC-HN-SII oil-testing centrifuge to concentrate the paramecia. The packed cells were then resuspended in a 1:1 mixture of Dryl's solution and Sten's solution ( $0.5 \mathrm{M}$-sucrose, $20 \mathrm{~mm}$-Tris, $2 \mathrm{mM}$ EDTA, $6 \mathrm{mM}-\mathrm{NaCl}$; pH 7.5) (Hansma \& Kung, 1975; Adoutte et al., 1980) and incubated for $10 \mathrm{~min}$ on ice. $\mathrm{CaCl}_{2} / \mathrm{KCl}$ solution was added to give a final concentration of $10 \mathrm{mM}$ and $30 \mathrm{mM}$, respectively. The cells were left in this solution for $10 \mathrm{~min}$ before centrifugation at 1600 r.p.m. $\left(20^{\circ} \mathrm{C}\right)$ in an IEC-HN-SII centrifuge. The pellet was resuspended in $1 \mathrm{ml}$ Dryl's solution, and homogenized with a Potter-Elvehjem homogenizer at $4^{\circ} \mathrm{C}$.

Electrophoresis and autoradiography. SDS-PAGE was done according to Laemmli (1970) on 8 and $10 \%(\mathrm{w} / \mathrm{v})$ polyacrylamide slab gels, and on $7.5-22.5 \%$ or $5-15 \%(\mathrm{w} / \mathrm{v})$ exponential gradient gels. Gels were stained with Coomassie Brilliant Blue R, then washed with methanol/acetic acid/water $(4 \cdot 5: 1: 4.5$, by vol.) and enhanced for $1 \mathrm{~h}$ with Enhance (New England Nuclear). Following this treatment the gel was placed into double-distilled $\mathrm{H}_{2} \mathrm{O}$ for $1 \mathrm{~h}$, and dried on Whatman filter paper. Dried gels were put on sheets of Kodak XRP-1 X-ray film and incubated at $-70^{\circ} \mathrm{C}$ for periods ranging from $3 \mathrm{~d}$ to 2 weeks.

Myoglobin, bovine serum albumin, ovalbumin, $\alpha$-chymotrypsinogen A, conalbumin (Sigma) and $\beta$ galactosidase (Worthington) were dissolved in sample buffer $[10 \%(\mathrm{v} / \mathrm{v})$ glycerol, $5 \%(\mathrm{v} / \mathrm{v}) 2$-mercaptoethanol, $2.3 \%(\mathrm{w} / \mathrm{v}) \mathrm{SDS}, 0.0625 \mathrm{M}-\mathrm{Tris} / \mathrm{HCl}, \mathrm{pH} 6.8$ ] at concentrations of $50 \mu \mathrm{g} \mathrm{ml}^{-1}$ and used as size markers. The positions of these non-radioactive size markers were determined by comparisons of autoradiographs with stained gels. 


\section{RESULTS}

Kappa particles were isolated and purified from Paramecium biaurelia (stock 7) cultures. In vitro labelling with ${ }^{35}$ S $]$ methionine, using Klebsiella pneumoniae samples as a control, was not successful. Although $K$. pneumoniae incorporated the label readily, there was insignificant incorporation of label by kappa, because homogenates from kappa-free paramecia showed a comparable incorporation when subjected to the in vitro system. However, kappa particles could be labelled in vivo, when radioactive bacteria were fed to a kappa-bearing paramecium culture. Usually, about $35 \%$ of the radioactivity originally added was incorporated by paramecium. In vivo labelled kappa particles could be purified from the paramecium homogenates (Fig. 1). All the radioactivity eluted in kappa-containing fractions sedimented together with the kappa particles, thus excluding the possibility of soluble contaminants.

Chloramphenicol inhibited cell division of paramecium at concentrations of $0.2 \mathrm{mg} \mathrm{ml}^{-1}$. At concentrations of $0.4 \mathrm{mg} \mathrm{ml}^{-1}$ it prevented in vivo labelling of kappa, when added $30 \mathrm{~min}$ before paramecium was fed with radioactive bacteria. The incorporation of ${ }^{35} \mathrm{~S}$ into paramecium proteins was not prevented, however. This was shown by using kappa-free cultures, and by measuring the radioactivity of homogenates from which kappa had been removed quantitatively by centrifugation at $17000 \mathrm{~g}$ for $10 \mathrm{~min}$.

Cycloheximide and the aminoglycoside G418, when used at concentrations of $1 \mathrm{mg} \mathrm{ml}^{-1}$ and $50 \mu \mathrm{g} \mathrm{ml}^{-1}$, respectively, significantly reduced the incorporation of ${ }^{35} \mathrm{~S}$ into paramecium proteins. However, they did not prevent it completely, and they did not eliminate the in vivo labelling of kappa.

Kappa proteins were subjected to electrophoresis on SDS-polyacrylamide gels and subsequent autoradiography. About 40 major bands were found with very distinctive bands of $165,86,78$, $59,52,41,40,18$ and $14 \mathrm{kDal}$ (Fig. 2). The pattern was essentially identical in experiments with cycloheximide as an inhibitor. Figure 3 shows the autoradiograph of kappa proteins from an

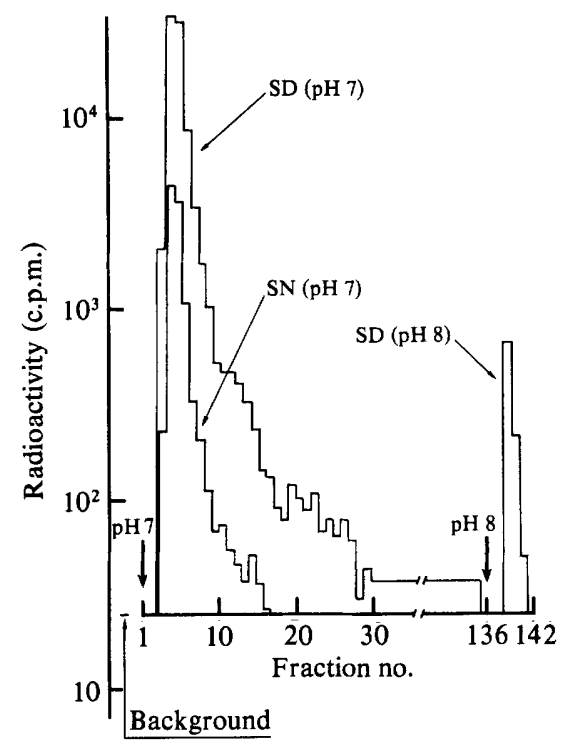

Fig. 1. Chromatographic profile of a radioactive 7K homogenate on a filter paper column. All fractions $(1.4 \mathrm{ml})$ were centrifuged at $17000 \mathrm{~g}\left(10 \mathrm{~min}, 4^{\circ} \mathrm{C}\right)$, and radioactivity was measured in $5 \mu \mathrm{l}$ of the supernatant. Sediments were dissolved in $100 \mu \mathrm{l}$ sample buffer, and radioactivity was measured in $5 \mu \mathrm{l}$ of this suspension. The start of elution with low ionic strength buffer $\mathrm{pH} 7$ ( $0.01 \mathrm{M}$-sodium phosphate) and with high ionic strength buffer $\mathrm{pH} 8(0.01 \mathrm{M}$-sodium phosphate, $0.5 \mathrm{M}-\mathrm{NaCl})$ is indicated by bold arrows. SD, sediment; SN, supernatant. Undigested food bacteria were eluted with low ionic strength buffer, and were usually found in fractions 5-20. 


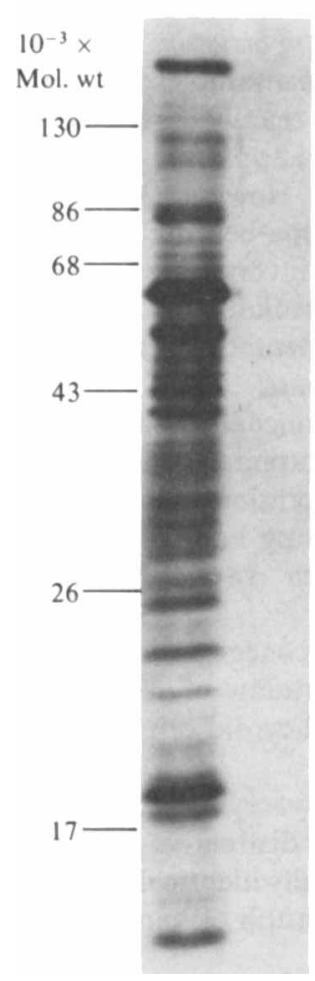

Fig. 2

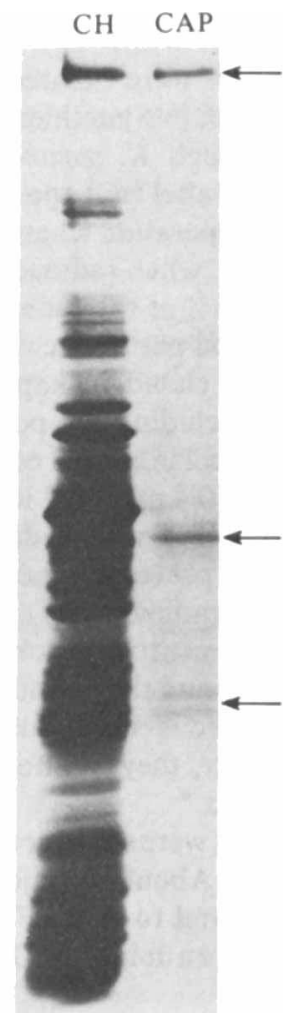

Fig. 3

Fig. 2. Autoradiograph of highly purified 7 kappa proteins on a $7 \cdot 5-22 \cdot 5 \%$ exponential gradient SDSpolyacrylamide gel. Kappas were labelled in vivo without inhibitors. Cells were deciliated before isolating kappa particles on a filter paper column. The size-marker positions were found by matching autoradiograph and stained gel.

Fig. 3. Autoradiograph of 7 kappa proteins on a 5-15\% SDS-polyacrylamide gradient gel. $\mathrm{CH}$, cycloheximide used during in vivo labelling at a concentration of $1 \mathrm{mg} \mathrm{ml}^{-1}$; CAP, chloramphenicol used at a concentration of $0.4 \mathrm{mg} \mathrm{ml}^{-1}$. The $\mathrm{CH}$ lane is overexposed in order to show bands present in the CAP lane.

experiment with cycloheximide and chloramphenicol as inhibitors. No bands were visible with a short exposure (2-3d), when chloramphenicol was used. However, a long (2-3 weeks) exposure revealed some bands in the kappa lane. The possibility that these bands were contaminants from food bacteria was excluded by the following experiments. Food bacteria, after labelling, were treated with lysozyme and proteinase $\mathbf{K}$, and autoclaved. This effectively reduced or eliminated all distinctive bands from the electrophoretic pattern of the bacterial proteins, but had no influence on the electrophoretic pattern of the kappa proteins (Fig. 4). Furthermore, when labelled food bacteria were mixed with a homogenate of unlabelled kappabearing paramecia before treatment on the filter paper column, the resulting kappa preparation was completely free from radioactivity.

On the other hand, when a kappa-free (7S) culture was labelled, homogenized and mixed with a kappa-bearing non-labelled culture before purification on the filter paper column, the resulting kappa preparation showed contaminating bands, totally unlike bacterial bands (Fig. 5). This provided further proof against bacterial contamination.

Figure 1 indicates that cytoplasmic contaminants were sedimented with kappa, because the supernatant was free from radioactivity, and a careful microscopic study of purified kappa preparations suggested cilia as possible cytoplasmic contaminants. This was confirmed in a 


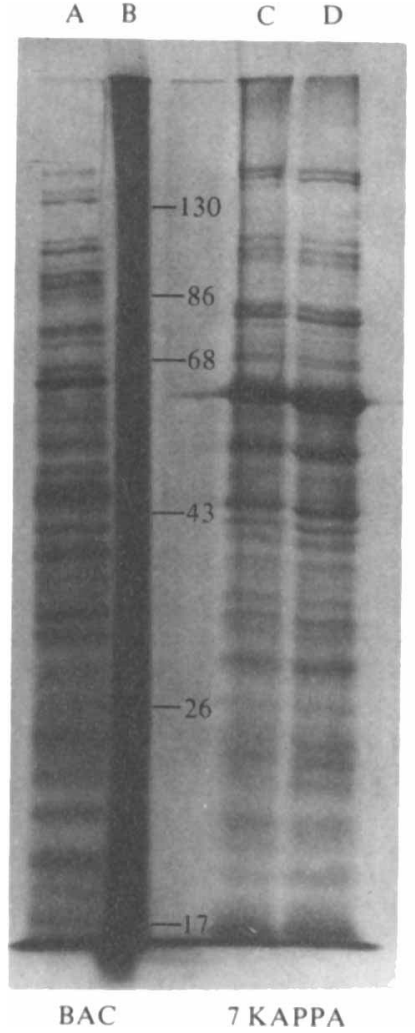

Fig. 4

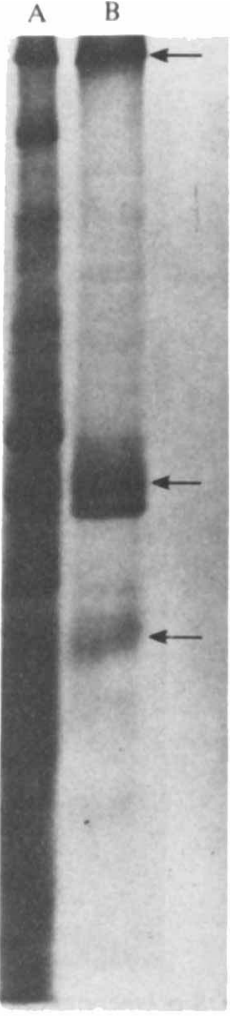

Fig. 5

Fig. 4. Autoradiograph of $K$. pneumoniae and 7 kappa proteins on a $10 \%$ SDS-polyacrylamide gel. BAC, bacterial proteins; A, autoclaved; B, treated with lysozyme, proteinase $\mathrm{K}$ and autoclaved. 7 Kappa, kappa proteins; C, from labelling experiment with bacteria, treatment as in B; D, from labelling experiment with autoclaved bacteria, as in $\mathrm{A}$. The positions of the molecular size markers (kDal) are indicated by the pointers.

Fig. 5. Autoradiograph showing cytoplasmic contaminants (arrowed) on an $8 \%$ SDS-polyacrylamide gel. A, extended autoradiograph of kappa proteins, labelled without inhibitors. B, autoradiograph of kappa proteins, isolated from a mixture of a non-radioactive $7 \mathrm{~K}$ and a radioactive $7 \mathrm{~S}$ culture.

repetition of both experiments (Fig. $6 a, b$ ) in which the contaminating bands disappeared if the labelled paramecia were deciliated before the isolation of kappa.

\section{DISCUSSION}

The purpose of this study was to see whether any proteins synthesized in the cytoplasm of paramecium move into kappa. Experiments where labelling was done in the presence of chloramphenicol should have shown many labelled cytoplasmic proteins in the cytoplasmic fraction, since chloramphenicol does not affect the protein synthesis on $80 \mathrm{~S}$ cytoplasmic ribosomes. The kappa fraction should have shown no symbiont proteins except those that were synthesized outside the symbiont.

The experiments confirmed the expectations regarding labelled cytoplasmic proteins. However, comparable autoradiography of kappa proteins revealed no labelled bands. On the other hand, when the autoradiography of the same gel was extended, some bands became visible. Since these bands did not resemble the general pattern of kappa proteins, they could not be explained as being due to incomplete inhibition by chloramphenicol. They could have been proteins that were synthesized in the cytoplasm, and had then moved into kappa. Control 
(a)

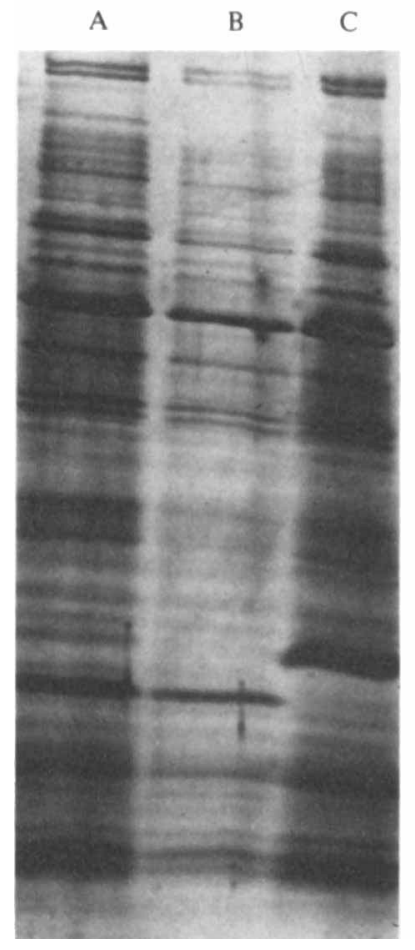

(b)

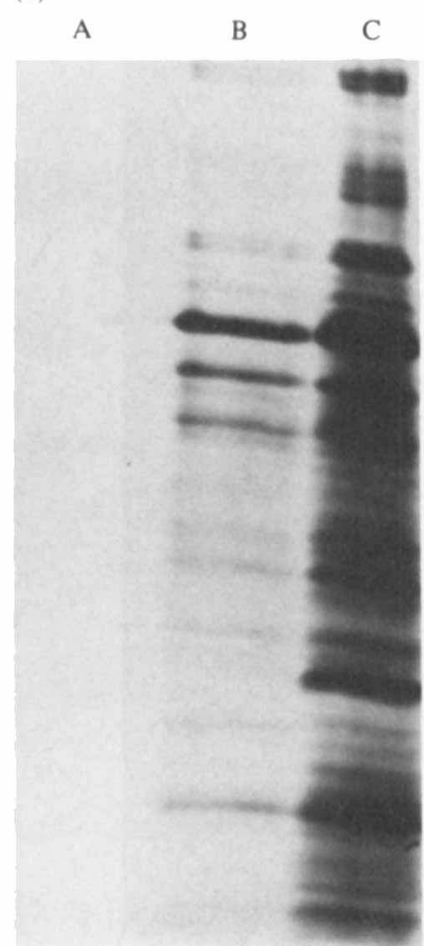

Fig. 6. (a) SDS-polyacrylamide gel (7.5-22.5\% exponential gradient) stained with Coomassie Brilliant Blue R. A, kappa proteins from a mixture as in Fig. 5, but with a deciliation step before mixing the homogenates. $\mathrm{B}$ and $\mathrm{C}$, two samples of kappa proteins, labelled in vivo without inhibitors. For details see text. (b) Autoradiograph of the gel shown in Fig. $6 a$. Note the absence of any contaminating bands in lane A.

experiments excluded contamination of the kappa preparation by proteins from food bacteria. Contaminating cytoplasmic proteins were found when kappa was isolated from a mixture of labelled kappa-free cells with non-labelled kappa-bearing cells. The symbiont-free cells still had the maintenance gene $\mathrm{K}$ for kappa. The $\mathrm{K}$ gene product was labelled in the $7 \mathrm{~S}$ cytoplasm, and kappa could have absorbed the gene product when both homogenates were mixed. However, one would have expected only one contaminating band if this were true.

The discovery of small numbers of cilia in purified kappa preparations established a possible source for cytoplasmic contamination that was easily testable. It was shown that, indeed, cytoplasmic contamination bands disappeared if the labelled symbiont-free culture was first deciliated, and the cilia were separated from the cell bodies before mixing the homogenates and isolating kappa. Kappa preparations obtained in this way were free from ciliary contaminants, as confirmed by light microscopy. When the experiment using chloramphenicol as an inhibitor was repeated, and the cells were deciliated before homogenization, again no bands were seen, even after extended autoradiography.

These results show that no major proteins found in kappa were made outside kappa in the host cytoplasm. Although kappa has previously been shown to be a bacterial endosymbiont (Preer $e t$ al., 1974a), these experiments demonstrate for the first time the existence of a prokaryotic translational system in kappa. This translational system seems to be non-functional in isolated kappa preparations, and even in crude cell homogenates, a finding which might be unique for 7 kappa. Isolated 7 kappa particles do not respire (J. R. Preer, Jr, unpublished), whereas stock 51 kappa symbionts do (Kung, 1970). Chloramphenicol was shown to be a potent inhibitor of 
protein synthesis in kappa. Cycloheximide and the aminoglycoside G418 influenced cytoplasmic protein synthesis, but did not eliminate it. They did not inhibit protein synthesis in kappa.

The filter paper column method yielded kappa preparations of extremely high purity when combined with a deciliation step before the homogenization of kappa-bearing cells.

The author thanks Mrs Friederike Schmidt for excellent assistance. He is grateful to Professor J. R. Preer, Jr for his advice during the course of this study and for his helpful comments on the manuscript. The work reported here was supported by a postdoctoral fellowship (DFG no. I3-Schm 544/1-1; 544/1-2) from the Deutsche Forschungsgemeinschaft to H. J. S. and by a grant from the National Science Foundation (NSF no. 80-22828) to J. R. Preer, Jr.

\section{REFERENCES}

Adoutte, A., Ramanathan, R., Lewis, R. M., Dute, R. R., LiNG, K., Kung, C. \& NeLson, D. L. (1980). Biochemical studies of the excitable membrane of Paramecium tetraurelia. Journal of Cell Biology 84, 717-738.

Ashwell, M. \& Work, T. S. (1970). The biogenesis of mitochondria. Annual Review of Biochemistry 39, 251-290.

BalsLey, M. (1966). Dependence of the kappa particles of stock 7 of Paramecium aurelia on a single gene. Genetics 54, 320.

Beale, G. H. \& JURAND, A. (1966). Three different types of mate-killer (mu) particle in Paramecium aurelia (syngen 1). Journal of Cell Science 1, 31-34.

DRYL, S. (1959). Antigenic transformation in Paramecium aurelia after homologous antiserum treatment during autogamy and conjugation. Journal of Protozoology 6 (suppl.), 25.

Hansma, H. G. \& KUNG, C. (1975). Studies of the cell surface of Paramecium. Biochemical Journal 152, 523-528.

KUNG, C. (1970). The electron transport system of kappa particles from Paramecium aurelia stock 51. Journal of General Microbiology 61, 371-378.

LAEMMLI, U. K. (1970). Cleavage of structural proteins during the assembly of the head of bacteriophage T4. Nature, London 227, 680-685.

LAW, M. F., ByrNe, J. C. \& Howley, P. M. (1983). A stable bovine Papillomavirus hybrid plasmid that expresses a dominant selective trait. Molecular and Cellular Biology 3, 2110-2115.

Mueller, J. A. (1966). Gel diffusion studies on a kappa antigen from Paramecium aurelia, syngen 4, stock 51. American Zoologist 6, 364-365.

Poyton, R. D. \& GRoOT, G. S. P. (1975). Biosynthesis of polypeptides of cytochrome $c$ oxidase by isolated mitochondria. Proceedings of the National Academy of Sciences of the United States of America 72, 172176.

PreER, J. R. JR (1977). The killer system in paramecium-kappa and its viruses. In Microbiology1977, pp. 576-578. Edited by D. Schlessinger. Washington, D. C. : American Society for Microbiology.

Preer, J. R., JR \& Preer, L. B. (1982). Revival of names of protozoan endosymbionts and proposal of Holospora caryophila nom. nov. International Journal of Systematic Bacteriology 32, 140-141.
Preer, J. R., JR \& Preer, L. B. (1983). Endosymbionts of protozoa. In Bergey's Manual of Systematic Bacteriology, vol. 1, pp. 795-811. Edited by N. R. Krieg. Baltimore: Williams \& Wilkins.

Preer, J. R., JR \& Stark, P. (1953). Cytological observations on the cytoplasmic factor 'kappa' in Paramecium aurelia. Experimental Cell Research 5, 478-491.

Preer, J. R., JR, Hufnagel, L. \& Preer, L. B. (1966). Structure and behaviour of $\mathbf{R}$ bodies from killer paramecia. Journal of Ultrastructure Research 15 , 131-143.

Preer, J. R., JR, Preer, L. B. \& Jurand, A. (1974a). Kappa and other endosymbionts in Paramecium aurelia. Bacteriological Reviews 38, 113-163.

Preer, L. B., Rudman, B. M., Preer, J. R., JR \& JURAND, A. (1974b). Induction of R bodies by ultraviolet light in killer paramecia. Journal of General Microbiology 80, 209-215.

SCHMIDT, H. J. (1982). Isolation of omikron-endosymbionts from mass cultures of Euplotes aediculatus and characterization of their DNA. Experimental Cell Research 140, 417-425.

Soldo, A. T. \& Godoy, G. A. (1973). Molecular complexity of paramecium symbiont lambda deoxyribonucleic acid : evidence for the presence of multicopy genome. Journal of Molecular Biology 73, 93108.

Soldo, A. T. \& Godoy, G. A. (1974). The molecular complexity of mu and pi symbiont DNA of Paramecium aurelia. Nucleic Acids Research 1, 387-396.

SonNEBoRn, T. M. (1950). Methods in the general biology and genetics of Paramecium aurelia. Journal of Experimental Zoology 113, 87-148.

SONNEBORN, T. M. (1959). Kappa and related particles in paramecium. Advances in Virus Research 6, 229356.

SONNEBORN, T. M. (1970). Methods in paramecium research. Methods in Cell Physiology 4, 241-339.

Steinkeler, J. A. \& MAHLER, H. R. (1980). Regulatory interactions between mitochondrial genes: exon and intron phenotypes observed in vivo can be expressed in vitro. Plasmid 4, 17-33.

Tzagoloff, A., Macino, G. \& Sebald, W. (1979). Mitochondrial genes and translation products. $A n-$ nual Review of Biochemistry 48, 419-441. 